\title{
Genetic Characterization by RAPD Analysis of Isolates of Fusarium oxysporum f. sp. erythroxyli Associated with an Emerging Epidemic in Peru
}

\author{
Amy J. Nelson, Karol S. Elias, E. Arévalo G., Lee C. Darlington, and Bryan A. Bailey
}

First and fifth authors: Biocontrol of Plant Diseases Laboratory, ARS, USDA, Beltsville, MD 20705; second author: Systematic Botany and Mycology Laboratory, ARS, USDA, Beltsville, MD 20705; third author: Universidad Nacional Agraria de la Selva, Tingo María, Peru; and fourth author: Weed Science Laboratory, ARS, USDA, Beltsville, MD 20705.

Accepted for publication 9 September 1997.

\section{ABSTRACT}

Nelson, A. J., Elias, K. S., Arévalo G., E., Darlington, L. C., and Bailey, B. A. 1997. Genetic characterization by RAPD analysis of isolates of Fusarium oxysporum f. sp. erythroxyli associated with an emerging epidemic in Peru. Phytopathology 87:1220-1225.

An epidemic of vascular wilt caused by Fusarium oxysporum f. sp. erythroxyli is currently occurring on Erythroxylum coca var. coca in the coca-growing regions of the Huallaga Valley in Peru. Random amplified polymorphic DNA (RAPD) analysis of isolates of the pathogen was undertaken to elucidate its genetic complexity, as well as to identify a specific DNA fingerprint for the pathogen. Two hundred isolates of Fusarium were collected from 10 coca-growing regions in Peru. Of these, 187 were confirmed to be $F$. oxysporum, and 143 of the $F$. oxysporum were shown to be pathogens of coca by a root-dip pathogenicity test. The pathogens could be grouped into two subpopulations based on RAPD analysis, and no polymorphism in RAPD pattern was observed among isolates of either subpopulation. Both subpopulations were present in the central Huallaga Valley, where earliest reports of the epidemic occurred. RAPD analysis could easily distinguish the isolates of $F$. oxysporum $\mathrm{f}$. sp. erythroxyli from the nonpathogenic isolates of $F$. oxysporum from $E$. coca var. coca, indicating its utility in DNA fingerprinting.
Fusarium oxysporum Schlechtend.:Fr. (19) causes extensive disease problems as a vascular wilt pathogen on a variety of crops worldwide. In Peru, an epidemic of wilt disease has emerged on coca, Erythroxylum coca Lam. var. coca (2), the source of the narcotic cocaine. The forma specialis responsible for this disease has been designated f. sp. erythroxyli, and its host range includes several Erythroxylum species in addition to E. coca $(17,18)$. Although definitive reports of the presence of the disease can be found as early as 1932, its incidence increased sharply in the 1980s, coinciding with the boom in coca production and the subsequent increased use of agricultural chemicals and introduction of a shortened cultivation time $(1,20)$. The disease now occurs in epidemic proportions in most of the coca-producing areas of the Huallaga Valley, with the exception of the southernmost regions (3). Little is known about the genetic complexity of $F$. oxysporum f. sp. erythroxyli populations in Peru or about the origin and spread of the pathogen, i.e., whether it arose as a single lineage in one location or arose independently in several locations.

Random amplified polymorphic DNA (RAPD) analysis (24) has many advantages as a means of characterizing genetic variability such as speed, low cost, minimal requirement for DNA, and lack of radioactivity. Major polymorphisms in RAPD pattern indicate genetic distinctness and can be used to distinguish unrelated groups. Minor polymorphisms may indicate genetic distinctness within

Corresponding author: A. J. Nelson; E-mail address: anelson@ asrr.arsusda.gov

Mention of a trademark name or proprietary product does not constitute a guarantee or warranty by the U.S. Department of Agriculture nor imply its approval to the exclusion of other products that may also be suitable.

Publication no. P-1997-1014-01R

This article is in the public domain and not copyrightable. It may be freely reprinted with customary crediting of the source. The American Phytopathological Society, 1997. groups or may occur because of experimental variability and, therefore, must be verified by repetition. RAPD analysis has been used effectively to distinguish between species of Fusarium $(23,27)$. RAPD analysis has also successfully delineated groups within $\mathrm{Fu}$ sarium species including $F$. avenaceum (27), F. graminearum (13), and $F$. moniliforme (23), as well as within formae speciales of $F$. oxysporum. One group was delineated within $F$. oxysporum f. sp. albedinis (22), two groups within f. sp. ciceris (9), two groups within $\mathrm{f}$. sp. cubense $(5,14)$, one or two groups within $\mathrm{f}$. sp. dianthi $(11,26)$, two or three groups within f. sp. pisi $(8,15)$, and three groups within f. sp. vasinfectum (4). For all of the formae speciales, except albedinis and dianthi, some minor polymorphisms in RAPD pattern were observed among isolates within each group.

The current study was undertaken to elucidate the genetic complexity of $F$. oxysporum f. sp. erythroxyli in Peru based on RAPD analysis and to provide insight into its geographic origin. A second objective was to develop a specific DNA fingerprint for $F$. oxysporum f. sp. erythroxyli.

\section{MATERIALS AND METHODS}

Fungal isolates. Field isolates were collected from an area in Peru where coca (E. coca var. coca) is cultivated on a large scale, covering much of the Huallaga Valley. The area was arbitrarily divided into 10 regions of near equal size, each region encompassing five field locations (Fig. 1). The field locations were surveyed for the presence of symptomatic coca plants. Plants that showed vascular wilt symptoms, or portions of those plants, were collected and brought to the laboratory at the Universidad Nacional Agraria de la Selva in Tingo María, Peru. Stem sections were taken from those plants and plated on slants of Komada's medium (10). In total, 200 isolates were collected. The isolates were brought to USDA-ARS facilities in Beltsville, MD, where each was singlespored, transferred to nährstoffarmer agar $\left(0.1 \% \mathrm{KH}_{2} \mathrm{PO}_{4}, 0.1 \%\right.$ $\mathrm{KNO}_{3}, 0.05 \% \mathrm{MgSO}_{4} \cdot 7 \mathrm{H}_{2} \mathrm{O}, 0.05 \% \mathrm{KCl}, 0.02 \%$ glucose, $0.02 \%$ 
saccharose, and 2\% agar) (12), and identified microscopically. Those isolates that were confirmed to be $F$. oxysporum were preserved by allowing them to colonize toothpicks on water agar. The colonized toothpicks were dried and stored at $4^{\circ} \mathrm{C}$.

Other formae speciales of $F$. oxysporum and other species of $\mathrm{Fu}$ sarium that were isolated from their hosts either in neighboring locations in Peru or in the United States and confirmed to be pathogenic on their respective hosts were processed as above. F. oxysporum f. sp. basilicum was isolated from Ocimum basilicum (gift of R. Larkin, USDA, Beltsville, MD); F. oxysporum f. sp. lycopersici from Lycopersicon esculentum (gift of R. Larkin); F. oxysporum f. sp. melonis from Cucumis melo (gift of R. Larkin); F. oxysporum f. sp. niveum from Citrullus vulgaris (gift of A. Keinath, Clemson University, Clemson, SC); F. acuminatum from Zea mays (gift of W. Mao, USDA, Beltsville, MD); F. culmorum from Zea mays (gift of W. Mao); F. graminearum from Zea mays (gift of W. Mao); and F. sambucinum from Oxalis tuberosa (gift of T. Icochea, International Potato Center, Lima, Peru).

Coca seedlings. Fruits were harvested from plants of $E$. coca var. coca at the USDA-ARS Weed Science Laboratory field test site in Kauai, HI. Fruits were soaked in $10 \%$ bleach for 5 min, rinsed in water, and then soaked in water several days until the pulp fermented. The softened pulp was removed and the seeds were sterilized in $10 \%$ bleach for $5 \mathrm{~min}$, rinsed with sterile water, and planted in Pro Mix potting soil (Premier Brands, Inc., Yonkers, NY) in seedling trays. The seedling trays were covered with plastic to retain moisture and maintained at $23^{\circ} \mathrm{C}$ with 12 -h days/12-h nights. After germination (approximately 1 month), the plastic was removed and the seedling trays were transferred to a greenhouse, maintained at 26 to $30^{\circ} \mathrm{C}$ with $12-\mathrm{h}$ days/12-h nights, and watered daily. Seedlings were grown to the six-leaf stage, which usually occurred 2 to 3 months after seeding.

Pathogenicity tests. Pathogenicity of all of the Fusarium isolates on E. coca var. coca was determined using a root-dip assay modified from that of Williams (25). Greater inoculum concentrations, inoculum incubation times, and overall pathogenicity test times were necessary, because E. coca var. coca is a woody plant. Pathogenicity tests were begun at weekly intervals, consisting of 20 to 30 isolates per test. In each test, a confirmed pathogenic isolate and a confirmed nonpathogenic isolate were included as controls. Each of the isolates was grown on potato dextrose agar (PDA), and plugs were used to initiate cultures in $100 \mathrm{ml}$ of potato dextrose broth. Cultures were grown for 3 days on an orbital shaker $(\sim 120 \mathrm{rpm})$ at $26^{\circ} \mathrm{C}$ with $12-\mathrm{h}$ days/12-h nights. The concentration of microconidia was determined for each culture, and it was diluted with water to a final concentration of $1 \times 10^{7}$ microconidia/ml in a total volume of $50 \mathrm{ml}$. Three dilutions were made for each isolate.

Coca seedlings at the six-leaf stage were removed from seedling trays, and their roots were trimmed to approximately half of their initial length and submerged in inoculum. Five seedlings were submerged in each $50 \mathrm{ml}$ of inoculum, a total of 15 seedlings per isolate. After treatment for $3 \mathrm{~h}$, the seedlings were planted in 4-inchdiameter pots (five seedlings per pot) in Pro Mix potting soil, and the soil was drenched with the inoculum. Plants were maintained in an environmentally controlled greenhouse cubicle with 12 -h days at $28^{\circ} \mathrm{C} / 12$-h nights at $22^{\circ} \mathrm{C}$.

Each week, plants were scored as healthy, chlorotic (many leaves dropped or yellowing leaves), or necrotic (all leaves dropped), and the stems of necrotic plants were cut at soil level. Three $1-\mathrm{cm}-$ long sections were cut from each stem beginning at the base of the stem. The sections were surface-disinfected in $10 \%$ bleach for 2 min, rinsed twice in sterile water, and plated on Komada's medium. The culture dishes were incubated at $26^{\circ} \mathrm{C}$ in the dark, and after 2 to 3 days, the vascular tissue was checked for colonization by $F$. oxysporum f. sp. erythroxyli. In diseased plants, $F$. oxysporum f. sp. erythroxyli grew out of both ends of each stem section, indicating successful colonization of the vascular tissue. In plants that died as a result of pruning injury or transplant shock, no colonization by $F$. oxysporum f. sp. erythroxyli was observed, and death occurred within days rather than weeks. Also, in such cases, leaves generally remained attached to the stem after wilting, in contrast to diseased plants in which leaves dropped immediately after wilting. Pathogenicity tests were continued for a total of 12 weeks. At 12 weeks, all remaining plants (healthy, chlorotic, or necrotic) were removed from the pots and checked for colonization by $F$. oxysporum $\mathrm{f}$. sp. erythroxyli as described above. The percentage of colonized plants was assessed for each isolate. The test allowed differentiation of the isolates pathogenic on coca from the nonpathogenic isolates. Isolates that caused symptoms of vascular wilt on any percentage of plants and that could be reisolated from the symptomatic vascular tissue were considered to be pathogens.

DNA isolation. Each isolate was transferred from PDA to $10 \mathrm{ml}$ of Czapek-Dox broth with $1 \%$ casamino acids in a 50-ml conical centrifuge tube. Cultures were grown on an orbital shaker $(\sim 120$ $\mathrm{rpm})$ at $26^{\circ} \mathrm{C}$ for 3 days. Cultures were transferred to a $15-\mathrm{ml}$ snapcap tube and centrifuged at $4,000 \times g$ for $10 \mathrm{~min}$ at $4^{\circ} \mathrm{C}$. The supernatant was poured off, and cultures were frozen at $-80^{\circ} \mathrm{C}$ for several hours and then lyophilized.

The lyophilized cultures were used for genomic DNA isolation according to the method of Rehner and Samuels (16) with minor modifications. Each lyophilized culture was ground directly in the snap-cap tube in liquid nitrogen with a sterile glass rod. The ground culture was transferred to a $1.5-\mathrm{ml}$ tube and suspended in $600 \mu \mathrm{l}$ of extraction buffer ( $2 \%$ sodium dodecyl sulfate, $100 \mathrm{mM}$ Tris$\mathrm{HCl}$ [pH 8.0], $100 \mathrm{mM} \mathrm{NaCl}$, and $10 \mathrm{mM}$ EDTA). Samples were incubated at $65^{\circ} \mathrm{C}$ for $30 \mathrm{~min}$, extracted with an equal volume of phenol/chloroform/isoamyl alcohol (25:24:1), and centrifuged at $7,500 \times g$ for $30 \mathrm{~min}$. Approximately $500 \mu \mathrm{l}$ of the upper aqueous phase was transferred to a clean $1.5-\mathrm{ml}$ tube, and the DNA was precipitated with $300 \mu \mathrm{l}$ of isopropanol at $-20^{\circ} \mathrm{C}$ for $30 \mathrm{~min}$. The tube was centrifuged at 7,500 $\times g$ for $2 \mathrm{~min}$ and dried briefly in a vacuum concentrator. The isolated DNA was dissolved in 50 to $100 \mu \mathrm{l}$ of Tris-EDTA buffer (10 mM Tris- $\mathrm{HCl}$ [pH 7.4] and $1 \mathrm{mM}$ EDTA [pH 8.0]) by heating for 5 to $10 \mathrm{~min}$ at $65^{\circ} \mathrm{C}$. Isolated DNA was stored at $4^{\circ} \mathrm{C}$ until it was used for RAPD analysis.

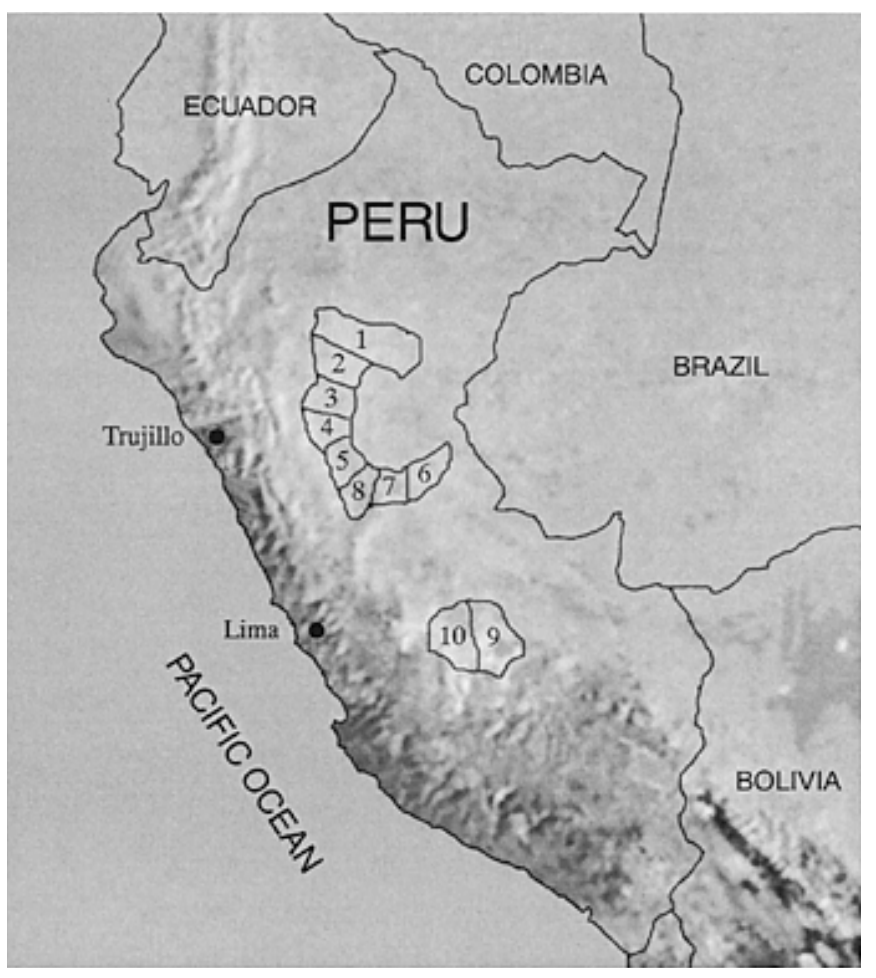

Fig. 1. Map of Peru showing the 10 regions within the coca-growing area from which isolates of Fusarium were obtained. 
RAPD analysis. Isolated Fusarium DNA was amplified by the RAPD method using the "A," "B," and "C" kits of random oligonucleotide (10-mer) primers from Operon Technologies, Inc. (Alameda, CA). All isolates were analyzed with the B-14 primer. Twenty isolates, representative of all of the coca-growing regions of Peru, were evaluated with all of the remaining primers from the A, B, and $C$ kits. RAPD analysis was repeated at least three times per isolate. Approximately $50 \mathrm{ng}$ of genomic DNA was combined with the following reaction mix to a final volume of $50 \mu \mathrm{l}: 10 \mathrm{mM}$ Tris$\mathrm{HCl}$ [pH 8.0], $50 \mathrm{mM} \mathrm{KCl}, 3 \mathrm{mM} \mathrm{MgCl} 2,0.001 \%$ gelatin, $100 \mu \mathrm{M}$ dNTPs, and $0.5 \mu \mathrm{M}$ primer. The DNA was denatured in the reaction mix for $5 \mathrm{~min}$ at $94^{\circ} \mathrm{C}$, and then 2 units of Taq DNA polymerase (Promega Corp., Madison, WI) was added to each tube. The reactions were amplified in a thermocycler (M. J. Research, Inc., Watertown, MA) for 45 cycles of $1 \mathrm{~min}$ at $94^{\circ} \mathrm{C}, 1 \mathrm{~min}$ at $36^{\circ} \mathrm{C}$, and $2 \mathrm{~min}$ at $72^{\circ} \mathrm{C}$. The final extension was continued for an additional $5 \mathrm{~min}$, and then reactions were held at $4^{\circ} \mathrm{C}$ until gel electrophoresis.

Amplified DNA was separated by electrophoresis on a $1 \%$ agarose gel in $1 \times$ Tris-borate-EDTA. The size of separated bands was determined by running in parallel a 1-kb DNA ladder (Gibco BRL, Gaithersburg, MD). Gels were stained with ethidium bromide to visualize the DNA, and photographs were taken using an MP4 Land Camera with 665 positive/negative black and white film (Polaroid Corp., Cambridge, MA).

\section{RESULTS}

Distribution of isolates. The area of the Huallaga Valley where coca is grown extensively was evaluated for the presence of coca plants exhibiting symptoms of vascular wilt disease. The disease was found to be present on coca plants in all of the coca-growing regions except region 10 (Fig. 1). A total of 200 fungal isolates was obtained from the nine regions where the disease was present. Few isolates were obtained from region 4 , because of limited access to the region. However, at least 10 isolates were collected from all of the other coca-growing regions. Of the 200 isolates collected, only 13 were not $F$. oxysporum (Table 1 ).

Pathogenicity tests. Root-dip inoculation tests indicated that most of the $F$. oxysporum isolates were pathogenic. Of the 187 isolates confirmed to be $F$. oxysporum, 143 were found to be pathogenic on E. coca var. coca (Table 1). Pathogenic isolates caused wilt symptoms on at least some inoculated plants and could be reisolated from the vascular tissue of the symptomatic plants. When vascular wilt occurred, the percentage of plants exhibiting wilt symptoms ranged from 30 to $100 \%$, with an average of $65 \%$. Necrosis generally began at 3 to 4 weeks postinoculation and was near completion by 8 to 12 weeks.

RAPD analysis of pathogenic isolates of $\boldsymbol{F}$. oxysporum. Genetic variability among the 143 pathogenic isolates from Peru was assessed by RAPD analysis. Using the random primer B-14, RAPD analysis of genomic DNA from the pathogenic isolates revealed

TABLE 1. Number of Fusarium isolates collected from different regions in Peru

\begin{tabular}{|c|c|c|c|c|c|c|c|}
\hline \multirow{2}{*}{ Region } & \multicolumn{3}{|c|}{ Not } & \multirow{2}{*}{$\begin{array}{c}\text { Non- } \\
\text { pathogenic }^{\mathrm{a}}\end{array}$} & \multirow{2}{*}{ Pathogenic $^{\mathrm{a}}$} & \multicolumn{2}{|c|}{ Subpopulation $^{\mathrm{b}}$} \\
\hline & Total & F. oxysporum & F. oxysporum & & & I & II \\
\hline 1 & 13 & 1 & 12 & 6 & 6 & 6 & 0 \\
\hline 2 & 13 & 1 & 12 & 3 & 9 & 9 & 0 \\
\hline 3 & 11 & 0 & 11 & 2 & 9 & 7 & 2 \\
\hline 4 & 5 & 2 & 3 & 0 & 3 & 3 & 0 \\
\hline 5 & 38 & 0 & 38 & 5 & 33 & 28 & 5 \\
\hline 6 & 35 & 4 & 31 & 9 & 22 & 16 & 6 \\
\hline 7 & 24 & 4 & 20 & 6 & 14 & 8 & 6 \\
\hline 8 & 50 & 1 & 49 & 5 & 44 & 32 & 12 \\
\hline 9 & 11 & 0 & 11 & 8 & 3 & 0 & 3 \\
\hline 10 & 0 & 0 & 0 & 0 & 0 & 0 & 0 \\
\hline Total & 200 & 13 & 187 & 44 & 143 & 109 & 34 \\
\hline
\end{tabular}

a On coca.

${ }^{\mathrm{b}}$ As defined by random amplified polymorphic DNA analysis (details in text). the presence of two subpopulations. The subpopulations could be distinguished by the different banding patterns obtained after amplification of genomic DNA from the isolates using the primer (Fig. 2). No polymorphism was observed among isolates of the two subpopulations. Evaluation of all of the pathogenic isolates revealed that only these two subpopulations were present in the collection from Peru. Both subpopulations showed a wide geographic distribution across the coca-growing regions in Peru; however, subpopulation I was generally more prevalent than subpopulation II in all regions (Table 1). Subpopulation II was less prevalent in the north (regions 1 to 4 ) than in other regions, and subpopulation I was not detected in region 9 (Table 1).

Further characterization by RAPD analysis of 20 isolates representative of all regions of Peru indicated that the two subpopulations could be distinguished using every primer from the A, B, and $\mathrm{C}$ kits, a total of 60 primers. With all of the primers, each isolate always fell into the same subpopulation, and no polymorphism among isolates within each subpopulation was ever observed. Representative primers that could distinguish the two subpopulations and that showed distinctive banding patterns after amplification of genomic DNA are primer A-5 (Fig. 3) and primer A-17 (Fig. 4).

RAPD analysis of nonpathogens and other Fusarium species. To establish the utility of RAPD analysis as a DNA fingerprint for $F$. oxysporum f. sp. erythroxyli, isolates of the pathogen were compared with nonpathogenic isolates of $F$. oxysporum from E. coca var. coca. Amplification of genomic DNA from all of the nonpathogenic isolates with the B-14 primer gave banding patterns distinct from either of the two RAPD patterns characteristic of the pathogenic isolates (Fig. 5). In addition, the two characteristic patterns of isolates of $F$. oxysporum f. sp. erythroxyli obtained

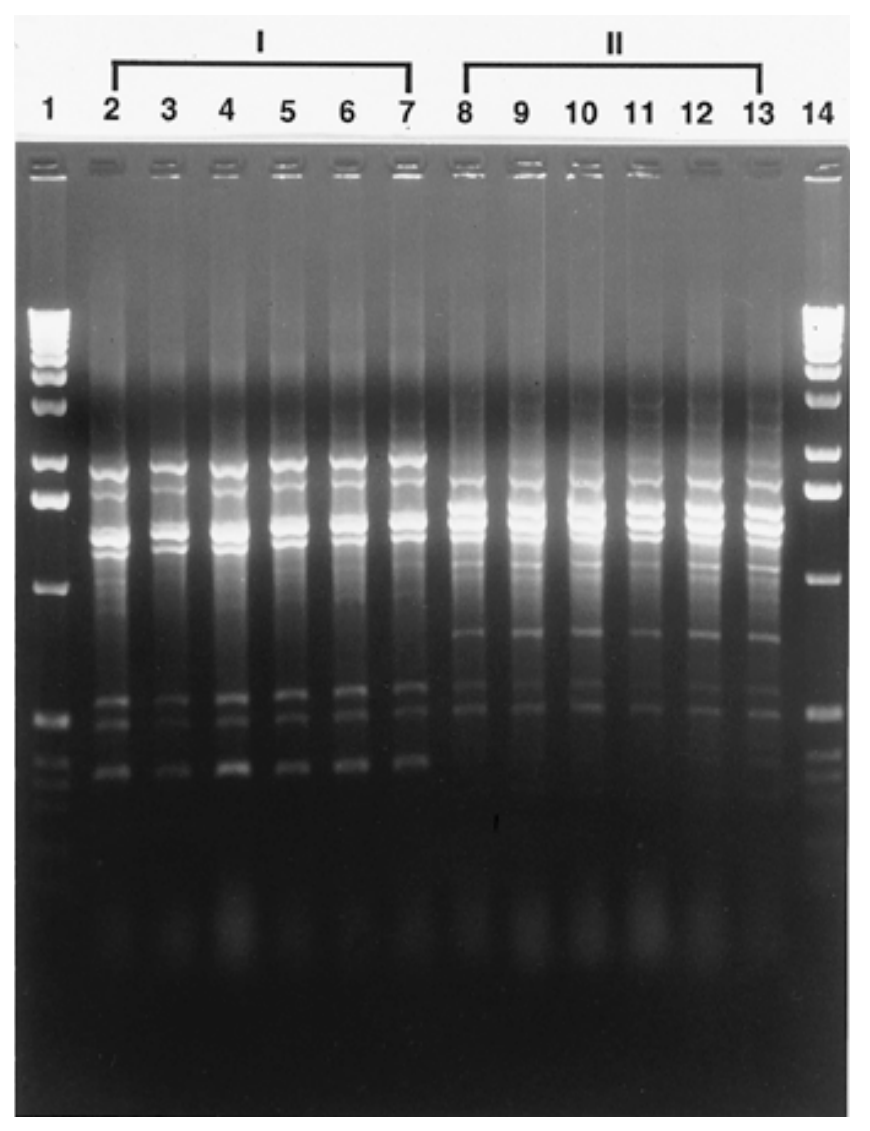

Fig. 2. Random amplified polymorphic DNA (RAPD) analysis of genomic DNA from isolates of Fusarium oxysporum f. sp. erythroxyli with the B-14 primer. The products were separated on a $1 \%$ agarose gel. Representative samples are shown. Lane 1, 1-kb DNA ladder; lanes 2 to 7, RAPD pattern of six isolates of subpopulation I; lanes 8 to 13, RAPD pattern of six isolates of subpopulation II; and lane 14, 1-kb DNA ladder. 
after amplification of genomic DNA with the B-14 primer were distinct from the patterns obtained with the other formae speciales of $F$. oxysporum and the other species of Fusarium tested (Fig. 6).

\section{DISCUSSION}

In the root-dip assay, the variation in measured rate and extent of symptom development and fungal colonization was likely dependent on the success of initial entrance of the fungus into the root tissue as determined by the degree of injury to the roots during the pruning process. The significant heterogeneity among coca seedlings also contributed to the rate and extent of symptom development, as did the season of the year. Hence, the root-dip assay was used strictly as a qualitative test of pathogenicity and was not an effective test of aggressiveness.

Our results indicate that there is little genetic variability among isolates of $F$. oxysporum f. sp. erythroxyli in Peru as identified by RAPD analysis. The pathogens can be divided into two subpopulations, and no polymorphism in RAPD pattern occurred among isolates of the two subpopulations. The data suggest that the isolates of $F$. oxysporum f. sp. erythroxyli are derived from two genetically distinct clones. The limited genetic variability observed among isolates of $F$. oxysporum f. sp. erythroxyli as indicated by RAPD analysis would be expected for a pathogen that became widespread relatively quickly as a result of an increase in production of the host plant.
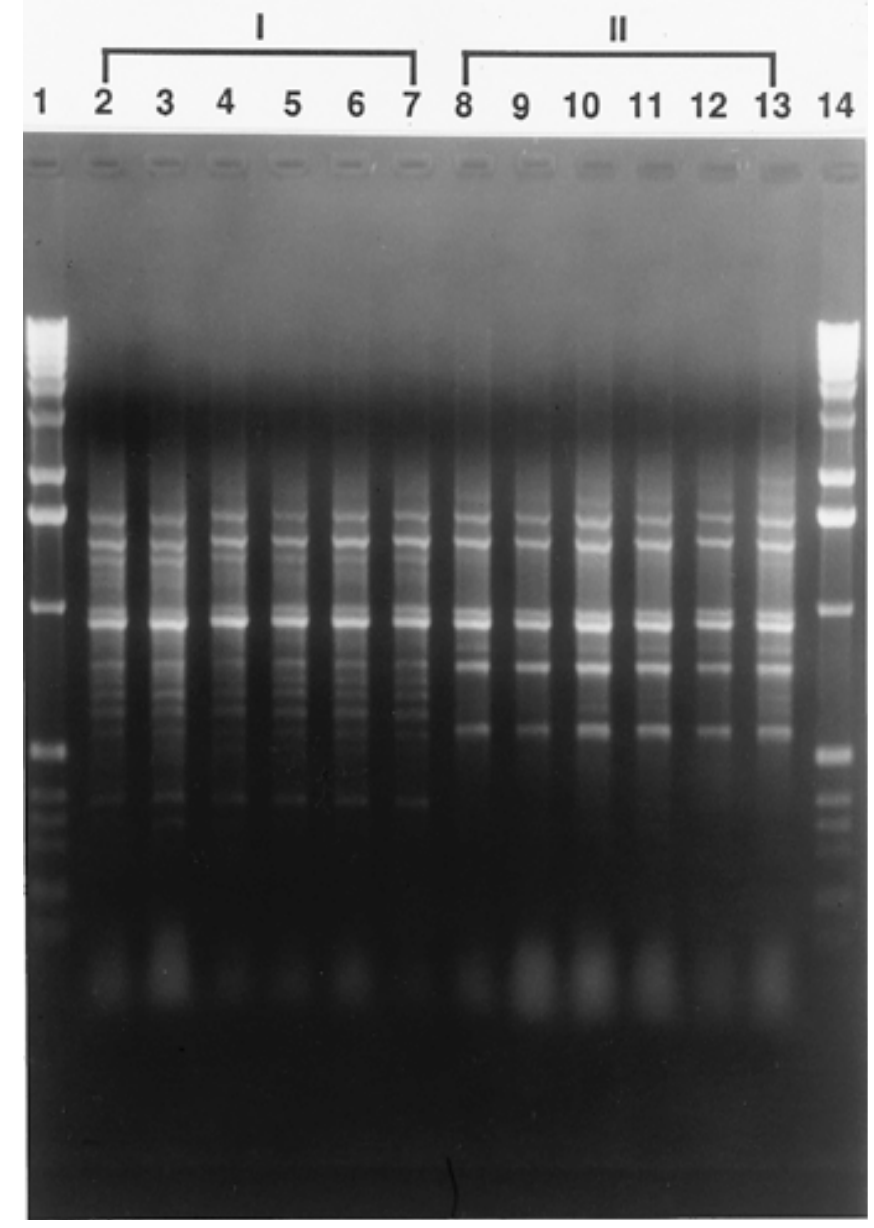

Fig. 3. Random amplified polymorphic DNA (RAPD) analysis of genomic DNA from isolates of Fusarium oxysporum f. sp. erythroxyli with the A-5 primer. The products were separated on a $1 \%$ agarose gel. Representative samples are shown. Lane 1, 1-kb DNA ladder; lanes 2 to 7, RAPD pattern of six isolates of subpopulation I; lanes 8 to 13, RAPD pattern of six isolates of subpopulation II; and lane 14, 1-kb DNA ladder.
The limited variability among isolates of $F$. oxysporum f. sp. erythroxyli makes it difficult to speculate as to the center of origin or the direction of spread of the epidemic. However, both of the subpopulations are represented in region 5, where the earliest reports of the epidemic occurred $(1,20)$. The complete homogeneity in RAPD pattern within the subpopulations contrasts with what has been observed for most other formae speciales of $F$. oxysporum $(4,5,8,9,14,15)$. Interestingly, two other pathogens of woody tree species showed similar results. No polymorphism was observed in RAPD analysis of 42 isolates of $F$. oxysporum $\mathrm{f}$. sp. albedinis from date palm (22) and near identical RAPD patterns were observed among 39 isolates of $F$. oxysporum from angsana (Pterocarpus indicus) (7).

Recent data indicate that $F$. oxysporum $\mathrm{f}$. sp. erythroxyli is transmitted by seed (J. Gracia-Garza, personal communication), and hence may be closely associated with the host population. However, the limited genetic variability observed among isolates of $F$. oxysporum f. sp. erythroxyli based on RAPD analysis is not likely to be attributable to coevolution with a homogeneous host population. E. coca is highly outcrossed and shows considerable genetic variability (6), providing ample opportunity for genetic evolution of the pathogen population.

The two subpopulations are well dispersed across the coca-growing regions in Peru. Although subpopulation II is not well represented in regions 1 to 4 and subpopulation I has not been detected in region 9, the two subpopulations are not isolated geographically. The data indicate that the isolates exist in two subpopulations in Peru independent of geographic location. This is in contrast to what

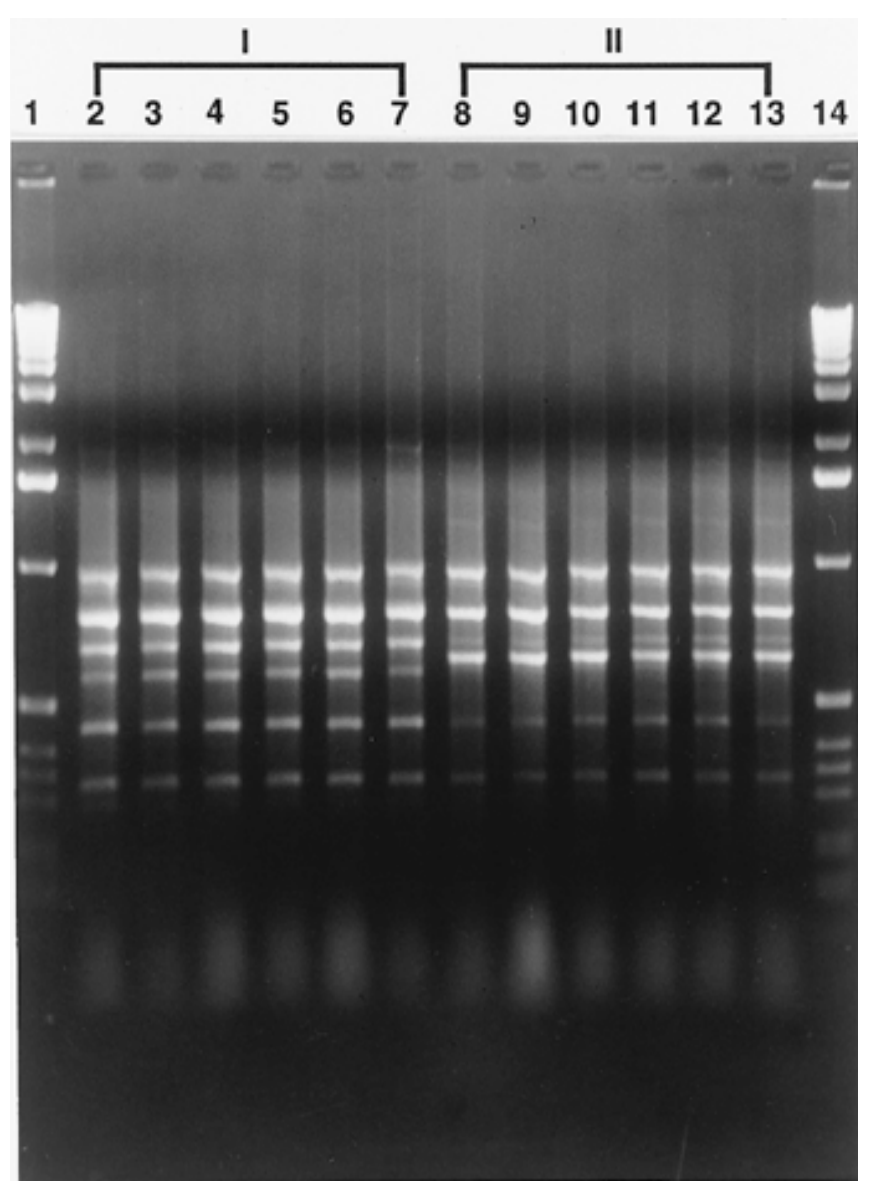

Fig. 4. Random amplified polymorphic DNA (RAPD) analysis of genomic DNA from pathogenic isolates of Fusarium oxysporum $\mathrm{f}$. sp. erythroxyli with the A-17 primer. The products were separated on a 1\% agarose gel. Representative samples are shown. Lane 1, 1-kb DNA ladder; lanes 2 to 7, RAPD pattern of six isolates of subpopulation I; lanes 8 to 13, RAPD pattern of six isolates of subpopulation II; and lane 14, 1-kb DNA ladder. 
was reported for $F$. oxysporum $\mathrm{f}$. sp. vasinfectum, in which a close correlation was observed between RAPD pattern and geographic location (4). However, a similar lack of correlation between RAPD pattern and geographic location was reported for $F$. oxysporum $\mathrm{f}$. sp. lycopersici (21) and f. sp. pisi (15). Our recent results indicate that subpopulation II is also present on the Peruvian coast at Trujillo on E. novogranatense var. truxillense and in Hawaii on E. coca var. coca. Subpopulation II appears to be identical to the pathogenic isolate En4 previously characterized from Hawaii (18). Coca was brought to Hawaii from both Trujillo and Cuzco (region 9), and the disease was reportedly present on plants that were germinated from the newly transported seed (L. C. Darlington, personal communication), hence subpopulation II did not arise independently in the different geographic locations. Recent reports have indicated that $F$. oxysporum $\mathrm{f}$. sp. erythroxyli may be present in the coca-growing regions in Colombia (1). It will be interesting to see if the same two subpopulations are present there.

Analysis of the same isolates from Peru by vegetative compatibility grouping (VCG) revealed an identical grouping of the isolates into two genetically distinct subpopulations (K. S. Elias, personal communication). Hence, the results from RAPD analysis and VCG analysis are corroborative and suggest a relative lack of genetic diversity among isolates of $F$. oxysporum f. sp. erythroxyli. Some correlation between RAPD data and VCG data was also found for F. oxysporum f. sp. albedinis $(22)$, f. sp. cubense $(5,14)$, f. sp. dianthi (26), and f. sp. pisi (15). For $F$. oxysporum f. sp.

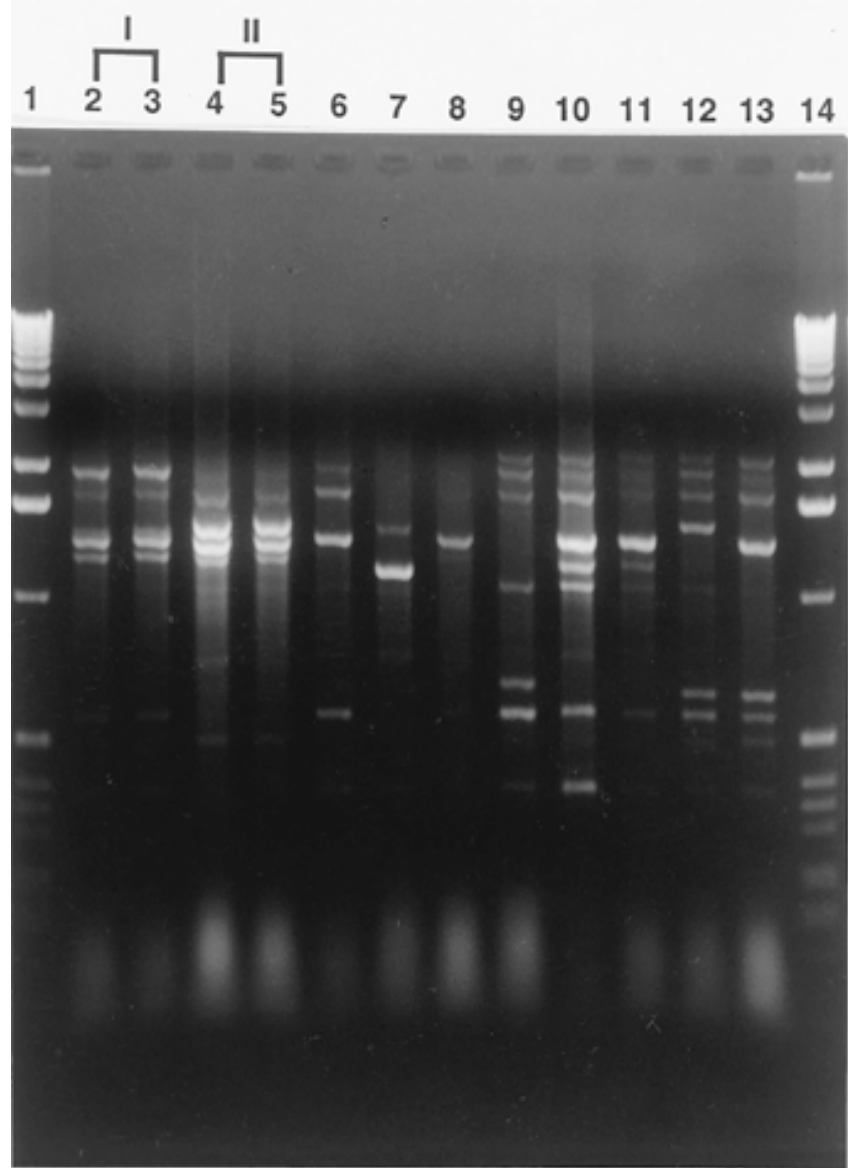

Fig. 5. Random amplified polymorphic DNA (RAPD) analysis of genomic DNA from nonpathogenic isolates of Fusarium oxysporum with the B-14 primer. The products were separated on a $1 \%$ agarose gel. Representative samples are shown. Amplified DNA from $F$. oxysporum f. sp. erythroxyli isolates is shown for comparison. Lane 1, 1-kb DNA ladder; lanes 2 to 3, RAPD pattern of two F. oxysporum f. sp. erythroxyli isolates of subpopulation I; lanes 4 to 5, RAPD pattern of two F. oxysporum f. sp. erythroxyli isolates of subpopulation II; lanes 6 to 13, RAPD pattern for eight different nonpathogenic isolates; and lane 14, 1-kb DNA ladder. cubense, several VCGs were found within each RAPD group, indicating that although RAPD analysis and VCG analysis may both be good indicators of genetic variability within formae speciales of $F$. oxysporum, the same groupings of isolates may not always be achieved with the two methods of analysis $(5,14)$.

Our results suggest that $F$. oxysporum f. sp. erythroxyli is distinguishable from other species of Fusarium by RAPD analysis, because no common RAPD bands were observed between $F$. oxysporum f. sp. erythroxyli and the other Fusarium species tested. This is in agreement with the results of Yli-Mattila et al. (27) and Voigt et al. (23). Also, F. oxysporum f. sp. erythroxyli appears to be distinguishable from other formae speciales by RAPD analysis, because distinct banding patterns were observed between $F$. oxysporum f. sp. erythroxyli and the other formae speciales tested. Testing of more isolates of other species of Fusarium and of other formae speciales of $F$. oxysporum will be necessary to confirm the uniqueness of f. sp. erythroxyli and to better understand its relationship to the other formae speciales within $F$. oxysporum and to other species of Fusarium.

That $F$. oxysporum f. sp. erythroxyli and nonpathogens of $F$. oxysporum from E. coca var. coca could be distinguished by RAPD analysis is consistent with reports for f. sp. albedinis (22) and f. sp. dianthi $(11,26)$, but contrasts with results for $F$. oxysporum

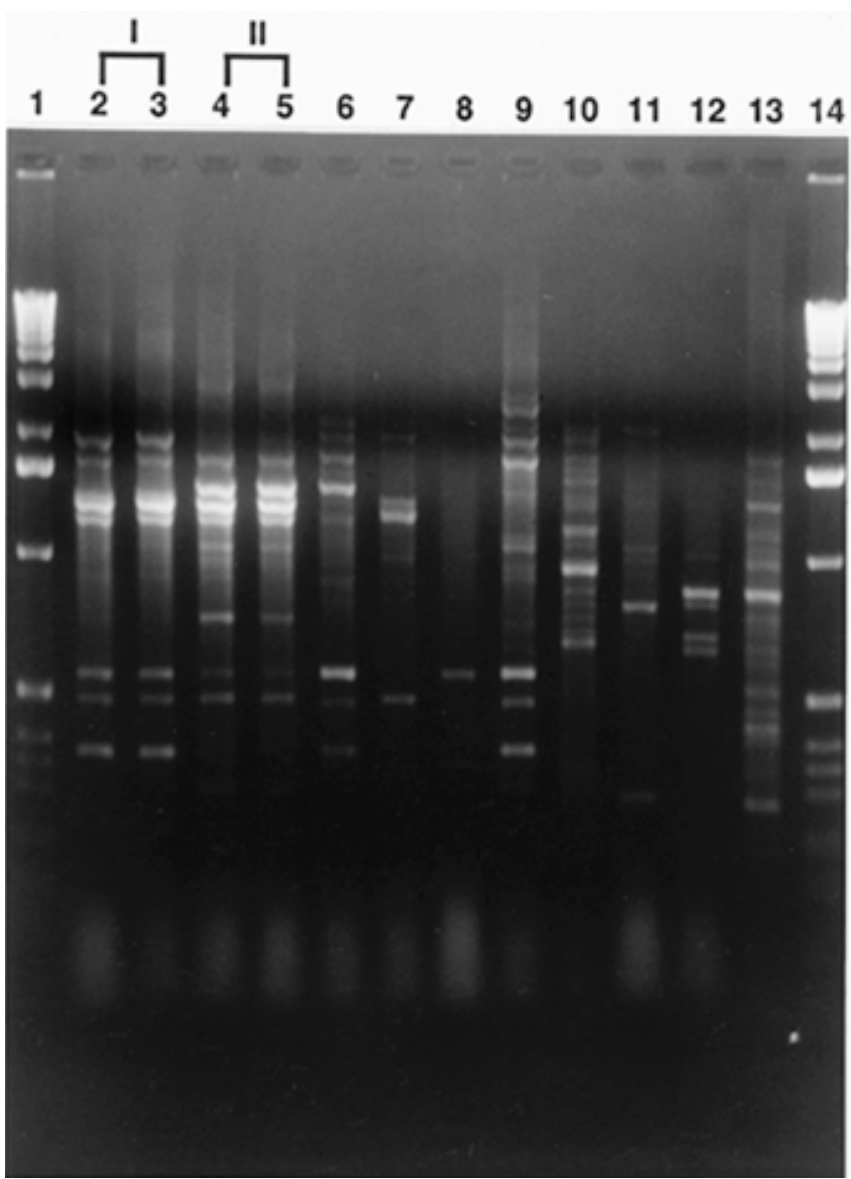

Fig. 6. Random amplified polymorphic DNA (RAPD) analysis of genomic DNA from various formae speciales of Fusarium oxysporum and various species of Fusarium with the B-14 primer. The products were separated on a $1 \%$ agarose gel. Representative samples are shown. Amplified DNA from $F$. oxysporum f. sp. erythroxyli isolates is shown for comparison. Lane 1, 1-kb DNA ladder; lanes 2 to 3, RAPD pattern of two $F$. oxysporum f. sp. erythrox$y l i$ isolates of subpopulation I; lanes 4 to 5, RAPD pattern of two $F$. oxysporum f. sp. erythroxyli isolates of subpopulation II; lane 6, F. oxysporum f. sp. basilicum; lane 7, F. oxysporum f. sp. lycopersici; lane $8, F$. oxysporum f. sp. melonis; lane $9, F$ oxysporum f. sp. niveum; lane $10, F$. acuminatum; lane $11, F$. culmorum; lane $12, F$. graminearum; lane $13, F$. sambucinum; and lane $14,1-\mathrm{kb}$ DNA ladder. 
f. sp. lycopersici (21). Hence, it appears that the relationship between pathogens and nonpathogens of $F$. oxysporum varies with the host species. Some studies have indicated that RAPD patterns can be used to distinguish isolates with differing levels of virulence in $F$. oxysporum f. sp. ciceris (9), f. sp. lycopersici (21), and f. sp. vasinfectum (4). No such comparisons can be made for $F$. oxysporum $\mathrm{f}$. sp. erythroxyli, because no virulence data are available for the different isolates given the limitations of the root-dip assay and the genetic variability among $E$. coca seedlings. In fact, the large amount of genetic variability among the host population has contributed to the problem in defining races of the pathogen. So, whereas RAPD analysis has been used to delineate at least some races of $F$. oxysporum f. sp. cubense (14), f. sp. pisi (8), and f. sp. vasinfectum (4), no such comparisons can be made at this time for $F$. oxysporum f. sp. erythroxyli.

RAPD analysis is an effective way to identify isolates of $F$. oxysporum f. sp. erythroxyli and distinguish them from nonpathogenic isolates of $F$. oxysporum from $E$. coca var. coca. Furthermore, RAPD analysis may also allow delineation of $F$. oxysporum f. sp. erythroxyli from other formae speciales of $F$. oxysporum and from other species of Fusarium. These results indicate that RAPD analysis can be effectively employed as a reliable DNA fingerprinting technique to study the spread of the pathogen.

\section{ACKNOWLEDGMENTS}

We thank M. Strem, R. Jacobs, and S. Perkins for technical assistance. We also thank W. Mao and R. Larkin of USDA, Beltsville, MD; A. Keinath of Clemson University, Clemson, SC; and T. Icochea of the International Potato Center, Lima, Peru, for providing isolates of the other species of Fusarium and the other formae speciales of F. oxysporum.

\section{LITERATURE CITED}

1. Anonymous. 1995. Hongo que destruye plantaciones de coca en Columbia no procede de Perú. El Comercio, March 20:A15.

2. Arévalo G., E., and Olivers N., J. 1992. Coca (Erythroxylum coca Lamb) in Alto Huallaga, San Martin, Peru. Page 59 in: Resúmenes Congr. Peru. Fitopatol., XII. Universidad Nacional Agraria de la Selva, Tingo María, Peru.

3. Arévalo G., E., Zúñiga C., L., and Cabezas H., O. 1994. Coca plant wilt and its ecological implications in Alto Huallaga. Page 17 in: Resúmenes Congr. Peru. de Fitopatol., XIII. Universidad Nacional Agraria de la Selva, Tingo María, Peru.

4. Assigbetse, K. B., Fernandez, D., Dubois, M. P., and Geiger, J.-P. 1994. Differentiation of Fusarium oxysporum $\mathrm{f}$. sp. vasinfectum races on cotton by random amplified polymorphic DNA (RAPD) analysis. Phytopathology 84:622-626.

5. Bentley, S., Pegg, K. G., and Dale, J. L. 1995. Genetic variation among a world-wide collection of isolates of Fusarium oxysporum f. sp. cubense analysed by RAPD-PCR fingerprinting. Mycol. Res. 99:1378-1384.

6. Bohm, B. A., Ganders, F. R., and Plowman, T. 1982. Biosystematics and evolution of cultivated coca (Erythroxylaceae). Syst. Bot. 7:121-133.

7. Crowhurst, R. N., King, F. Y., Hawthorne, B. T., Sanderson, F. R., and Choi-Pheng, Y. 1995. RAPD characterization of Fusarium oxysporum associated with wilt of angsana (Pterocarpus indicus) in Singapore. Mycol. Res. 99:14-18.

8. Grajal-Martín, M. J., Simon, C. J., and Muehlbauer, F. J. 1993. Use of random amplified polymorphic DNA (RAPD) to characterize race 2 of Fusarium oxysporum f. sp. pisi. Phytopathology 83:612-614.
9. Kelly, A., Alcalá-Jiménez, A. R., Bainbridge, B. W., Heale, J. B., PérezArtés, E., and Jiménez-Díaz, R. M. 1994. Use of genetic fingerprinting and random amplified polymorphic DNA to characterize pathotypes of Fusarium oxysporum f. sp. ciceris infecting chickpea. Phytopathology 84:1293-1298.

10. Komada, H. 1975. Development of a selective medium for quantitative isolation of Fusarium oxysporum from natural soil. Rev. Plant Prot. Res. 8:114-124.

11. Manulis, S., Kogan, N., Reuven, M., and Ben-Yephet, Y. 1994. Use of the RAPD technique for identification of Fusarium oxysporum f. sp. dianthi from carnation. Phytopathology 84:98-101.

12. Nirenberg, H. 1976. Untersuchungen über die morphologische und biologische Differenzierung in der Fusarium-Sektion Liseola. Mitt. Biol. Bundesanst. Land- Fortwirtsch. Berl. Dahlem 169:1-117.

13. Ouellet, T., and Seifert, K. A. 1993. Genetic characterization of Fusarium graminearum strains using RAPD and PCR amplification. Phytopathology 83:1003-1007.

14. Pegg, K. G., Shivas, R. G., Moore, N. Y., and Bentley, S. 1995. Characterization of a unique population of Fusarium oxysporum $\mathrm{f}$. sp. cubense causing Fusarium wilt in Cavendish bananas at Carnarvon, Western Australia. Aust. J. Agric. Res. 46:167-178.

15. Pomázi, A., Wittner, A., Pesti, M., and Hornok, L. 1994. PCR-generated simple RFLP-probe differentiates three distinct groups within Fusarium oxysporum f. sp. pisi. Acta Phytopathol. Entomol. Hung. 29:203-213.

16. Rehner, S. A., and Samuels, G. J. 1994. Taxonomy and phylogeny of Gliocladium analysed from nuclear large subunit ribosomal DNA sequences. Mycol. Res. 98:625-634.

17. Sands, D. C., Darlington, L., McCarthy, M. K., Pilgeram, A. L., and Ford, E. J. 1995. An effective and host-specific pathogen of Erythroxylum spp. (Abstr.) Phytopathology 85:1118.

18. Sands, D. C., Ford, E. J., Miller, R. V., Sally, B. K., McCarthy, M. K., Anderson, T. W., Weaver, M. B., Morgan, C. T., Pilgeram, A. L., and Darlington, L. C. 1997. Characterization of a vascular wilt of Erythroxylum coca caused by Fusarium oxysporum f. sp. erythroxyli forma specialis nova. Plant Dis. 81:501-504.

19. Snyder, W. C., and Hansen, H. N. 1940. The species concept in Fusarium. Am. J. Bot. 27:64-67.

20. Stevenson, S. 1991. Peru farmers blame U.S. for coca-killing fungus. Miami Herald, June 2:19A.

21. Suleman, P., Straney, D. C., Saleh, A., Tohamy, A. M., and Madkour, M. 1994. Variation in virulence, phytoalexin tolerance and polymorphism in DNA markers among isolates of Fusarium oxysporum f. sp. lycopersici. (Abstr.) Phytopathology 84:1075.

22. Tantaoui, A., Ouinten, M., Geiger, J.-P., and Fernandez, D. 1996. Characterization of a single clonal lineage of Fusarium oxysporum f. sp. albedinis causing Bayoud disease of date palm in Morocco. Phytopathology 86:787-792.

23. Voigt, K., Schleier, S., and Brückner, B. 1995. Genetic variability in Gibberella fujikuroi and some related species of the genus Fusarium based on random amplification of polymorphic DNA (RAPD). Curr. Genet. 27: 528-535.

24. Williams, J. G. K., Kubelik, A. R., Livak, K. J., Rafalski, J. A., and Tingey, S. V. 1990. DNA polymorphisms amplified by arbitrary primers are useful as genetic markers. Nucleic Acids Res. 18:6531-6535.

25. Williams, P. H. 1981. Fusarium yellows. Pages 124-129 in: Screening Crucifers for Multiple Disease Resistance. P. H. Williams, ed. University of Wisconsin, Madison.

26. Wright, G. F. K., Guest, D. I., Wimalajeewa, D. L. S., and van Heeswijck, R. 1996. Characterisation of Fusarium oxysporum isolated from carnation in Australia based on pathogenicity, vegetative compatibility and random amplified polymorphic DNA (RAPD) assay. Eur. J. Plant Pathol. 102:451-457.

27. Yli-Mattila, T., Paavanen, S., Hannukkala, A., Parikka, P., Tahvonen, R., and Karjalainen, R. 1996. Isozyme and RAPD-PCR analyses of Fusarium avenaceum strains from Finland. Plant Pathol. 45:126-134. 